\title{
Evaluation of pregerminative treatments in gulupa seeds (P. edulis f. edulis Sims).
}

\author{
María Antonia Martínez Camargo ${ }^{1}$, Ana Cruz Morillo Coronado ${ }^{2}$, \\ Edilberto Cepeda Mora ${ }^{3}$, Sandra Yaneth Mesa Fernández ${ }^{4}$
}

\begin{abstract}
The genus Passiflora, commonly known as fruits of passion, includes numerous species, including gulupa (Passiflora edulis f. edulis), of nutracetic and economic importance, both for consumption in nature and for its agro-industrial applicability. This research was developed to evaluate the effects of various pre-germinative treatments on the germination of gulupa seeds from the municipality of Ramiriquí (Boyacá), such as: exposure to hydrogen peroxide $\left(\mathrm{H}_{2} \mathrm{O}_{2}\right)$, hypochlorite of sodium $(\mathrm{NaOCl})$, gibberellic acid $\left(\mathrm{GA}_{3}\right)$, distilled water imbibition and stratification at $4{ }^{\circ} \mathrm{C}$, in varying concentrations and exposure times ( 24 and 48 hours), using an experimental design completely random, with three repetitions of 50 seed each one. Statistical analysis showed significant differences between treatments, with $\mathrm{H}_{2} \mathrm{O}_{2}$ being $15 \%$ the most effective, with a germination percentage (PG) of $88 \%$ in exposed seeds for 48 hours. In the presence of $\mathrm{NaOCl}$ the percentages were lower $36-40 \%$. GA 3 at $100 \mathrm{ppm}$ for 24 hours recorded $51 \% \mathrm{PG}$, at the other concentrations of this growth regulator and exposure times this value was lower. The use of $\mathrm{H}_{2} \mathrm{O}_{2}$ has not been reported as a treatment to induce germination in the genus Passiflora. These results can be applied for the treatment of seeds in plant species can be a viable, effective, economical and easily applicable alternative.
\end{abstract}

Index terms: Passiflora, gulupa, germination, hydrogen peroxide, gibberellic acid, sodium hypochlorite.

\section{Avaliação de tratamentos pré-germinativos em sementes de Gulupa (P. edulis f. edulis Sims).}

Corresponding author: mamartinez@sena.edu.co

Received: December 15, 2019 Accepted: March 05, 2020

Copyright: All the contents of this journal, except where otherwise noted, is licensed under a Creative Commons Attribution License.

\section{(cc) $\mathbf{E Y}$}

Resumo - O gênero Passiflora, comumente conhecido como frutos da paixão, inclui numerosas espécies, entre as quais o gulupa (Passiflora edulis f. edulis), conhecido como maracujá-roxo, de importância nutracética e econômica, tanto para o consumo in natura quanto para a sua aplicabilidade agroindustrial. A presente investigação foi desenvolvida para avaliar os efeitos de vários tratamentos pré-germinativos na germinação de sementes de gulupa do município de Ramiriqui (Boyacá), tais como: exposição ao peróxido de hidrogênio $\left(\mathrm{H}_{2} \mathrm{O}_{2}\right)$, hipoclorito de sódio $(\mathrm{NaOCl})$, ácido giberélico $\left(\mathrm{GA}_{3}\right)$, embebição em água destilada e estratificação a $4{ }^{\circ} \mathrm{C}$, em concentrações e tempos de exposição variáveis ( 24 e 48 horas), em delineamento experimental inteiramente casualizado, com três repetições de 50 sementes cada. A análise estatística mostrou diferenças significativas entre os tratamentos, sendo o $\mathrm{H}_{2} \mathrm{O}_{2}$ a $15 \%$ o mais eficaz, com uma porcentagem de germinação (PG) de $88 \%$ nas sementes expostas por 48 horas. Na presença de hipoclorito de sódio, as porcentagens foram inferiores a 36-40\%. $\mathrm{O} \mathrm{GA}_{3}$ a $100 \mathrm{ppm}$, por 24 horas, registrou $51 \%$ de PG, em outras concentrações desse regulador de crescimento, e nos tempos de exposição esse valor foi menor. $\mathrm{O}$ uso de peróxido de hidrogênio não foi relatado como tratamento para induzir germinação no gênero Passiflora. Considerando os resultados obtidos nesta pesquisa, sua aplicação no tratamento de sementes, em espécies vegetais pode ser uma alternativa viável, eficaz, econômica e de fácil aplicação.

Termos para indexação: Passiflora, gulupa, germinação, peróxido de hidrogênio, ácido giberélico, hipoclorito de sódio.

\footnotetext{
'Biologist - Master's Student in Biological Sciences - Universidad Pedagógica y Tecnológica de Colombia. Instructor Plant Biotechnology, National Learning Service, SENA. Duitama, Colombia. E-mail: mamartinez@sena.edu.co(ORCID 0000-0002-2028-8123)

${ }^{2}$ Agricultural Engineer. PhD. Associate Professor Universidad Pedagógica y Tecnológica de Colombia. Research group: CIDE-GMBC. Tunja - Colombia. ana.morillo@uptc.edu.co.E-mail (ORCID 0000-0003-3125-0697)

${ }^{3}$ Agricultural Engineer. Professional Greenhouse Production. National Learning Service, SENA. Duitama, Colombia. E-mail: ecepda@sena. edu.co (ORCID 0000-0002-4718-6450)

${ }^{4}$ Agrobiotechnology technologist. Research Assistant. National Learning Service, SENA. Duitama, Colombia. E-mail: smesaf@sena.edu.co(0Rcid 0000-0001-9889-269X)
} 


\section{Introduction}

Pasifloras stand out for their economic, medicinal and ornamental value, especially for the fruit that is used for its flavor characteristics, aroma, nutritional content, antioxidant activity, nutraceutical and pharmaceutical applications (SILVA and BOTTOLI, 2014). Among the cultivated species of the genus Passiflora are passion fruit (P. edulis var. flavicarpa), granadilla (P. ligularis), gulupa ( $P$. edulis $\mathrm{f}$ edulis), curuba ( $P$. tripartita var. mollissima (Kuth) Holm-Nielsen \& Jorgensen) and badea (P. quadrangularis). The genus Passiflora comprises more than 500 species. They are distributed in North and South America, the Caribbean region, the Galapagos Islands, Africa, Asia, Oceania, the Philippines and Australia. Colombia and Brazil are centers of diversity; with 30\% of registered pasiflora species (150 in Brazil and 170 in Colombia) (CERQUEIRA-SILVA et al., 2018). In general, species belonging to the genus Passiflora are spread asexually through grafting, cuttings and in vitro culture of tissues; and sexual pathway from seed, method most commonly used in most of these species (SILVA et al., 2018; FALEIRO et al., 2019). The period for germination has been estimated between 10 days and three months, with low germination rates and irregular seedling formation in some cases (DELANOY et al., 2006; MAROSTEGA et al., 2017). In this sense, Gutierrez et al. (2011) indicate that these methodologies generate planting materials of heterogeneous quality, with low and variable germination percentages, low population of established plants and therefore reduced yields. Despite the greater variability for plant germination and seed unevenness, seed propagation is the most widely used for most passiflora species due to the ease of the method compared to others, the difficulty in vegetative propagation of some species and high cost in other forms of propagation. In addition, as most species are allogamous, the use of clones or genetically similar materials would make production difficult. This point is necessary for the basis of seed propagation and the alternative would be the selection of genetically superior materials and uniformity in the establishment of seedlings.

The seed of these species presents physical and chemical difficulties, called latency or exogenous dormancy, that is to say that the testa is of stony context and has a resin that makes it waterproof, leading to low germination percentages (ELLIS et al., 1985; HARTMANN et al., 2002; GUTIERREZ et al., 2011; RAMÍREZ et al., 2015,). Dormancy has been reported in species of $P$. quadrangularis, $P$. suberosa, $P$. nitida, $P$. foetida, $P$. alata, $P$. cincinnata (MAROSTEGA et al., 2017), $P$. edulis $f$ edulis, $P$. ligularis and $P$. maliformis (GUTIÉRREZ et al., 2011), P. setacea (PADÚA et al., 2011), P. edulis var flavicarpa (RAMIREZ et al., 2015), P. actinia (GRZYBOWSKI et al., 2019). Hartmann and Kessler (2011) indicate that a combination of mechanical and physiological dormancy is present for $P$. xalatocaerulea, P. mollisima and P. tricuspsis. Due to the dormancy problems present in the cover of pasiflora seeds, various pregerminative treatments have been applied with the aim of inducing rapid and uniform germination.

Methodologies for overcoming dormancy include stratification (temperature variation) and scarification (mechanical and chemical) (HARTMANN et al., 2002). Pre-germinative treatments that have been evaluated in species of the genus Passiflora include: fermentation in sucrose, immersion in gibberellic acid $\left(\mathrm{GA}_{3}\right)$, potassium nitrate $\left(\mathrm{KNO}_{3}\right)$, immersion in sulphuric acid $\left(\mathrm{H}_{2} \mathrm{SO}_{4}\right)$, salicylic acid, scarification of partial testa by performing apical, basal and seed punctures, temperature alternation, combinations of temperature and lighting regimes, cold stratification and mycorrhizal inoculation (Glomus fasciculatum) (MABUNDZA et al., 2010; GUTIERREZ et al., 2011; VELASQUEZ et al., 2012; RAMIREZ et al., 2015; GRZYBOWSKI et al., 2019) in which the results obtained to break the dormancy were variable in terms of the germination time and the germination percentage obtained (PG). Another substance that has been tested in some plant species for chemical scarification is hydrogen peroxide $\left(\mathrm{H}_{2} \mathrm{O}_{2}\right)$. Oxygen-reactive species (ROS) play a major role in physiological, developmental and plant defense processes (FICHMAN et al., 2019).

Hydrogen peroxide is part of this family, and in species such as Pisum sativum and Cucumis melo stimulation of early germination and growth has been demonstrated, articulating an interaction between cellular redox state and plant hormones during (BARBA et al., 2012). Due to its chemical characteristics it could also be used for seed scarification by softening the testa and in turn stimulating the germination of the viable embryo of the pasifloras. Pregerminative treatments that include hydrogen peroxide scarification have not been reported in the family Pasifloracea. Due to the variability of results obtained in applying the methodologies available in several species of Passiflora and the need to determine a viable and reproducible germination protocol for the production of uniform quality plant material with technical criteria of species of economic interest, the objective of this research was to evaluate the effect of chemical-type pre-germline treatments with gibberellic acid, sodium hypochlorite and hydrogen peroxide, at times and concentrations variables, in gulupa seeds.

\section{Materials y methods}

\section{Plant Material}

The seeds used were selected from ripe fruits harvested from plants from commercial crops in the municipality of Ramiriquí (Boyacá) and in good phytosanitary condition, 10 plants were chosen randomly, 
pollinated naturally, the fruits were directly harvested from the plant. After the pollination, it is required within 28-35 days for the fruit formation, and for filling them, 90 days. In summary, the fruits were harvested at 120 days approximately after the pollination.

In the Plant Biotechnology laboratory of the National Learning Service (SENA) (Boyacá - Colombia), manual extraction of seeds was carried out, subsequently they underwent a fermentation process for 72 hours, after this aril was removed, to prevent fungal proliferation, submerged in $\mathrm{NaOCl}$ at 3\% (Commercial concentration $5.25 \% \mathrm{w} / \mathrm{v}$ ) for 15 minutes, followed by three washes with distilled water, 1 minute at a time and stored at room temperature until use.

Morphology of fruits and seeds. 10 fruits were chosen randomly from the ones harvested in the field. For the characterization of the fruits, the diameter, weight and number of seeds per fruit were recorded according to Orjuela et al (2011) and Icontec NTC 4101 standards of 1997, issued for passifloras such as gulupa and granadilla. The morphological analysis of the seeds was performed by observation to the stereoscope.

\section{Pre-germinative treatment}

Treatments are:

i.Control - untreated (ST), seeds that were extracted, fermented, removed aril and sown in greenhouse conditions.

ii. Hydrogen peroxide $\left(\mathrm{H}_{2} \mathrm{O}_{2}\right)$ : The seeds were immersed in the hydrogen peroxide solution at concentrations of 20 and $15 \%(\mathrm{v} / \mathrm{v})$, dilutions with respect to the commercial concentration of $30 \% \mathrm{w} / \mathrm{v}(100$ volumes), for 24 and 48 hours.

iii. Sodium hypochlorite at $5.25 \%(\mathrm{w} / \mathrm{v})$, the seeds were submerged for 24 and 48 hours.

iv. Seeds in gibberellic acid $\left(\mathrm{GA}_{3}\right)$ solution at concentrations of 50 and $100 \mathrm{ppm}$, for 24 hours and 48 hours,

v. Water imbibition: The seeds were immersed in distilled water for 24 and 48 hours.

vi. Cold stratification at $4{ }^{\circ} \mathrm{C}$, for 7 and 14 days prior to planting in greenhouse conditions.

All seeds after being subjected to the various pregerminative treatments were washed with distilled water three times, 1 minute at a time, and subsequently sown under described greenhouse conditions.

\section{Germination conditions.}

The planting under greenhouse conditions was carried out in sterile peat substrate brand Pindstrup plus, pH 5.5 - 6.0, type of fertilizer medium, which composition corresponds for each $\mathrm{Kg}$ of peat to: 0.18 of NPK, $0.00090 \mathrm{~kg}$ of microelements, $1.27 \mathrm{~g}$ of nitrate, $0.99 \mathrm{~g}$ of ammonium. Germination trays of 250 sockets were used. The volume of peat was $2.5 \mathrm{~g}$ equivalent to $3.12 \mathrm{ml}$ per socket. Irrigation was carried out to conserve the required and sufficient moisture without the addition of fertilizers. Approximate temperature, $25{ }^{\circ} \mathrm{C}$ during the day and 18 ${ }^{\circ} \mathrm{C}$ at night, in dark conditions. A seed was considered germinated, when the presence of the seeds with plumules or cotyledons emerged was observed. For the verification of presence and length of the root, plantlets from the tray were extracted randomly.

\section{Germination indices}

The experiment was conducted in a completely random design with 15 treatments and three replicas of 50 seeds each, for a total of 150 seeds per treatment. Germination assessment was recorded every $48 \mathrm{~h}$ for 45 days following the ISTA methodology (2013). The data obtained were used to find the mean germination time (TMG) following the formula of Thompson (1970) and Cardenas (2011):

$$
\mathrm{TMG}=\sum_{i=1}^{k} n_{i} \times t_{i} / \sum_{i=1}^{k} n_{i}
$$

where $\mathrm{t}=$ time elapsed since planting, $\mathrm{ni}=$ number of seeds germinated in the interval ti- (ti-1). The Germination Percentage (PG) and mean speed of germination (MSG) was estimated to have been found according to Ranal and Santana (2006), and Cárdenas (2011): $\mathrm{PG}=\left(\mathrm{N} / \mathrm{N}_{\mathrm{S}}\right)$ X 100; where: $\mathrm{N}=$ Number of germinated seeds $\mathrm{y} \mathrm{Ns}=$ Number of total seeds; MSG $=\Sigma\left(n_{i} / t_{i}\right)$; where, $n_{i}$ number of seeds germinated on the $i$-th day and $t$ time in days for germination on the $i$-th day. . Additional data of plantlets' height shoot were registered at the end of the term of germination.

Statistical analysis. The data recorded to quantify the germination percentage and the average germination time were analyzed using ANOVA variance analysis. When the test showed differences between the treatments, the Scott Knott's test $(\mathrm{P} \leq 0.05)$ was applied to determine the treatments that affect gulupe seed behavior. Statistical analyses were performed using $\operatorname{Sisvar}{ }^{\circledR}$ software (FERREIRA, 2014).

\section{Results and discussion}

\section{Morphology of fruits and seeds}

The collected gulupa fruits had a dark purple coloration and a smooth bark. The weight of the selected fruits ranged from 35 to 54 grams, the measurements of the equatorial diameter between 4.4 and $5.1 \mathrm{~cm}$, and the polar diameter between 5.1 and $5.8 \mathrm{~cm}$. The number of seeds counted per fruit had values between 110 and 186 seeds. 
Overall, the average weight of the fruits was 45.68 grams, polar diameter of $4.9 \mathrm{~cm}$, and the equatorial diameter of $5.41 \mathrm{~cm}$ and 155.9 seeds per fruit. The seeds observed had hard testa, endosperm and heart-shaped shape, reticulated or slit in dark to black. These results differ somewhat from those reported by Carvajal et al. (2012), who evaluated gulupa fruits from six locations, whose equatorial diameter was between 5.5 and $5.76 \mathrm{~cm}$ and polar diameter of 5.53 and $6.6 \mathrm{~cm}$. The number of seeds per fruit was 167 to 183 . Franco et al. (2014) concluded that the polar diameter was greater than the equatorial diameter in gulupa fruits evaluated at 112 days after flowering, 5.72 and $5.32 \mathrm{~cm}$, respectively. The authors concluded that the characteristics of the fruits at the end of their growth and development depend on their provenance.

\section{Seed germination}

Germination is epigeal and the emergence of seedlings is fanerocotilar. In the greenhouse conditions evaluated, germination was recorded 24 days after planting, starting with the emergence of the radicle and the cotyledonous leaves observed in the germination trays. In this sense, Silva et al. (2018) found that for six species of Passiflora, germination occurred between 14 and 28 days after planting. Other reports suggest that the estimated period is between 10 and 90 days (DELANOY et al., 2006). Therefore, the germination times of the gulupa materials evaluated in this study are within the reported range for species of the genus Passiflora and it can be inferred that this depends on the origin of the fruit, and treatments pre-germinations to which the seeds are subjected.

\section{Evaluation of pre-germinative treatments.}

Analysis of germination percentages (PG) obtained in the various pretreatments shows statistically significant differences (Table 1). In general, the minimum germination values for the whole experiment were $33 \%$ and the maximum values were $88.7 \%$. These results are in the PG range obtained by Marostega et al. (2017) from 54 to $86 \%$, Ramírez et al. (2015) with 67.9\% and Gutierrez et al. (2011) of up to $94 \%$ PG in immersion with $96 \%$ sulfuric acid. In contrast, Velázquez et al. (2012) obtained 17\% of PG with chemical pretreatments, however, when the seeds were stored at $4{ }^{\circ} \mathrm{C}$ for 15 days prior to planting, the PG was $75 \%$. It is clear that the results of $\mathrm{PG}$, in the same species of Passiflora or in others belonging to the same genus, have not been uniform even though the pregerminative treatments were the same or similar. In various species of Passiflora there are problems in the germination of seeds, related to the presence of dormancy, recalcitrance, among others (FALEIRO et al., 2019). The breakdown of dormancy in the seed, is controlled by endogenous physical factors and growth-regulating hormones (ABA and $\mathrm{GA}_{3}$ ) (WILLIS et al., 2014; NONOGAKI, 2017).
The use of chemicals to break dormancy has been widely referenced in the literature, with variable results between species belonging to the genus Passiflora and even among research reported in the same species. In all evaluated treatments, including untreated seeds (ST), variable germination percentages were presented depending on the chemical used as pretreatment (Hydrogen Peroxide - $\mathrm{H}_{2} \mathrm{O}_{2}$, Gibberellic Acid - $\mathrm{GA}_{3}$, Sodium Hypochlorite$\mathrm{NaOCl}$ ), the concentration and/or exposure time of the seeds. Treatments with better PG responses by chemical concentration and exposure time correspond to hydrogen peroxide. The days on which the onset of seed germination was recorded were 24 days after planting and the last at 43 days. No seedling emergency was observed prior to day 24 and no new emergencies were reported in the germination trays after day 43 . Figure 1 shows cumulative PG data at $25,32,39$ and 43 days after planting, evidenced that at 25 days, seeds imbibided in water for $48 \mathrm{~h}$ obtained the lowest PG value $(9.3 \%)$ while seeds in $\mathrm{H}_{2} \mathrm{O}_{2}$ had values between 20 and $38.7 \%$, pre-treatments in $\mathrm{GA}_{3}$ and $\mathrm{NaOCl}$ recorded similar GPs, between 10 and 32\%. Germination values were presented 33 days after planting throughout the test, in a range between 32 and $76 \%$ of PG. At 39 and 43 days the largest PG achieved was 80 and $88 \%$, respectively, corresponding to seeds exposed to $\mathrm{H}_{2} \mathrm{O}_{2}$.

In other research and species, the effect of $\mathrm{H}_{2} \mathrm{O}_{2}$ had already been reported at different concentrations, on the increase in the germination percentage. Nandi et al. (2017), they observed that the use of $\mathrm{H}_{2} \mathrm{O}_{2}$ to $1 \%$ in Capsicum annuum seeds was the most effective concentration in relation to the increase in $\mathrm{PG}$, vigor rate and percentage of mycelial inhibition. In this regard, Szopinska (2014) evaluated the germination, vigor and health of Zinnia elegans seeds, found that depending on the concentration of $\mathrm{H}_{2} \mathrm{O}_{2}$ and time, fungal infestation was significantly reduced, thus checking the effect and property peroxide antimicrobials, thus showing that the treatment of this species with $\mathrm{H}_{2} \mathrm{O}_{2}$ at $3 \%$ for 20 minutes positively affected germination. However, a drop-off effect was observed in zinnia cultivar named Kirke, when the concentration of $\mathrm{H}_{2} \mathrm{O}_{2}$ was high, reducing germination and vigor in some of its trials. Similar results are reported by Sasaki et al. (2005) in rice seeds, who found that treatments with high concentrations of $\mathrm{H}_{2} \mathrm{O}_{2}$ (500 and $1000 \mathrm{mM}$ ) significantly decreased the fresh weight of seedlings, while treatments with concentrations between 5 and $100 \mathrm{mM}$ of $\mathrm{H}_{2} \mathrm{O}_{2}$ had the against effect. Pretreatments with $\mathrm{GA}_{3}$, bleaching solution, and $\mathrm{H}_{2} \mathrm{O}_{2}$ with exposure time for 24 hours were evaluated in Psidium guajava seeds. The best results were obtained at 300 ppm $\mathrm{GA}_{3}$ with $40 \% \mathrm{PG}$, while $\mathrm{H}_{2} \mathrm{O}_{2}$ obtained PG values close to 25\% (HEJAZI et al., 2018). In pea seeds imbibition with hydrogen peroxide at $20 \mathrm{mM}$ to 12 and 24 hours increased germination, obtaining a PG of $75 \%$ compared to the control treatment as well as the growth of the seedling. Although, the authors indicate 
that concentrations between 40 and $100 \mathrm{Mm}$ stimulate germination may also influence abnormal plant growth (BARBA-ESPIN et al., 2012).

This research did not show that the highest concentrations of 15 and $20 \%$ of $\mathrm{H}_{2} \mathrm{O}_{2}$ produced malformations in the seedlings of $P$. edulis $f$. edulis, the subsequent transplantation performed from the germination trays to the head-on phase, did not register abnormalities.

$\mathrm{H}_{2} \mathrm{O}_{2}$ is a reactive molecule that plays a dual role in the physiological and developmental processes of the plant, and in the mechanisms of stress resistance. The negative or positive functions involving $\mathrm{H}_{2} \mathrm{O}_{2}$ in biological systems depend on their concentration, physiological conditions and the specificities of the processes affected by $\mathrm{H}_{2} \mathrm{O}_{2}$ (WOJTYLA et al., 2016). Barba et al. (2012), they showed that $\mathrm{H}_{2} \mathrm{O}_{2}$ coordinates the onset of germination in pea, acting as a priming factor involving specific changes at the protein, transcriptomic and hormonal level, via MAPK (mitogen-activated protein kinases route) accelerating the process germination probably due to the invigoration of the seed.

Table 1. Effect of germinative pretreatments on germination percentage (PG), mean germination time (TMG) and mean speed of germination (MSG) of gulupa seeds (Passiflora edulis f edulis Sims).

\begin{tabular}{|c|c|c|c|c|c|}
\hline \multirow{2}{*}{ Treatment } & \multirow{2}{*}{$\begin{array}{l}\text { Exposure time } \\
\text { (hours) }\end{array}$} & \multirow{2}{*}{$\begin{array}{l}\text { Shoot length } \\
(\mathrm{cm})\end{array}$} & \multicolumn{3}{|c|}{ Germination Indexes } \\
\hline & & & $\% \mathrm{PG}$ & TMG & MSG \\
\hline $\mathrm{H}_{2} \mathrm{O}_{2} 20 \%$ & 24 & $2,9 \mathrm{a}$ & $82,7 \mathrm{a}$ & 31,3 & $1,36 \mathrm{a}$ \\
\hline $\mathrm{H}_{2} \mathrm{O}_{2} 20 \%$ & 48 & $2,8 \mathrm{a}$ & $80,7 \mathrm{a}$ & 28,7 & $1,46 \mathrm{a}$ \\
\hline $\mathrm{H}_{2} \mathrm{O}_{2} 15 \%$ & 24 & $2,7 \mathrm{a}$ & $80,0 \mathrm{a}$ & 29,4 & $1,41 \mathrm{a}$ \\
\hline $\mathrm{H}_{2} \mathrm{O}_{2} 15 \%$ & 48 & $2,4 \mathrm{~b}$ & 88,7 a & 32,9 & $1,39 \mathrm{a}$ \\
\hline $\mathrm{NaOCl} 5.25 \%$ & 24 & $2,6 \mathrm{~b}$ & $36,0 \mathrm{~b}$ & 24,9 & $0,74 \mathrm{~b}$ \\
\hline $\mathrm{NaOCl} 5.25 \%$ & 48 & $1,4 \mathrm{~d}$ & $40,7 \mathrm{~b}$ & 30,5 & $0,70 \mathrm{~b}$ \\
\hline $\mathrm{GA}_{3} 50 \mathrm{ppm}$ & 24 & $2,7 \mathrm{a}$ & $33,3 \mathrm{~b}$ & 30,5 & $0,56 \mathrm{~b}$ \\
\hline $\mathrm{GA}_{3} 50 \mathrm{ppm}$ & 48 & $2,4 \mathrm{~b}$ & $39,3 \mathrm{~b}$ & 29,3 & $0,69 \mathrm{~b}$ \\
\hline $\mathrm{GA}_{3} 100 \mathrm{ppm}$ & 24 & $2,5 \mathrm{~b}$ & $51,3 \mathrm{~b}$ & 27,1 & $0,94 \mathrm{~b}$ \\
\hline $\mathrm{GA}_{3} 100 \mathrm{ppm}$ & 48 & $2,2 \mathrm{c}$ & $46,7 \mathrm{~b}$ & 30,1 & $0,78 \mathrm{~b}$ \\
\hline $\mathrm{H}_{2} \mathrm{O}$ & 24 & $2,3 \mathrm{c}$ & $33,3 \mathrm{~b}$ & 27,7 & $0,61 \mathrm{~b}$ \\
\hline $\mathrm{H}_{2} \mathrm{O}$ & 48 & $2,8 \mathrm{a}$ & $52,0 \mathrm{~b}$ & 31,5 & $0,84 \mathrm{~b}$ \\
\hline ST & & $2,3 \mathrm{~b}$ & $41,3 \mathrm{~b}$ & 28,5 & $0,77 \mathrm{~b}$ \\
\hline Cold stratification $4{ }^{\circ} \mathrm{C}$ & 7 days & $1,8 \mathrm{c}$ & $62,6 \mathrm{~b}$ & 39,9 & $0,85 \mathrm{~b}$ \\
\hline Cold stratification $4{ }^{\circ} \mathrm{C}$ & 14 days & $1,4 \mathrm{~d}$ & $46,0 \mathrm{~b}$ & 40,3 & $0,57 \mathrm{~b}$ \\
\hline $\mathrm{CV}(\%) *$ & & 7,87 & 7,07 & 4,87 & 20,0 \\
\hline
\end{tabular}

Means not followed by the same letter on the column differ from each other, according to the Scott-Knott test, $\mathrm{p}<0.05$. Coefficient variation percentage.

Several research revised and reported by Bailly (2019) indicate that the probable site of reactive oxygen species (ROS) production might be either the mitochondria or the NADPH oxidases of the plasma membrane. It is proposed that the inhibition of NADPH oxidase leads to delayed germination. It is suggested that after imbibition, the resurgence of mitochondrial respiration in the seed might leading to ROS production Accumulation of $\mathrm{H}_{2} \mathrm{O}_{2}$ may increase the rates of protein carbonylation and protein turnover, as well as decreasing the electron pressure in the mitochondrial electron transport chain, allowing the provision of reducing equivalents (NADPH) to the thioredoxin system (via the pentose phosphate pathway), which is involved in the regulation of seed germination and seedling development. In addition, $\mathrm{H}_{2} \mathrm{O}_{2}$ accumulation may influence the hormone balance by increasing gibberellins (GAs) and decreasing abscisic acid (ABA) and ethylene via 1-aminocyclopropane-1-carboxylic acid
(ACC) (BARBA et al., 2012; BAILLY, 2019).

In this research, according to the studies conducted and the available literature, we can infer that $\mathrm{H}_{2} \mathrm{O}_{2}$ could act through the molecular mechanisms described above to increase the PG of gulupa seeds, in which the presence of a thick, waterproof testa is related to the reported dormancy for this species. In this sense, peroxide could also act at the level of softening the testa and subsequent rupture allowing to improve the PGs. Lariguet et al. (2013), in Arabidopsis indicate that ROS molecules (reactive oxygen species) and especially $\mathrm{H}_{2} \mathrm{O}_{2}$ would have an important role during the rupture of the testa and endosperm prior to the protrusion of the radicle, by regulating the expression of genes that encode hydrolyzing enzymes of these structures. In the presence of 5.25\% sodium hypochlorite, PG was presented in the range between 36 and $40 \%$, in 24 to 48 hours of exposure, respectively. 


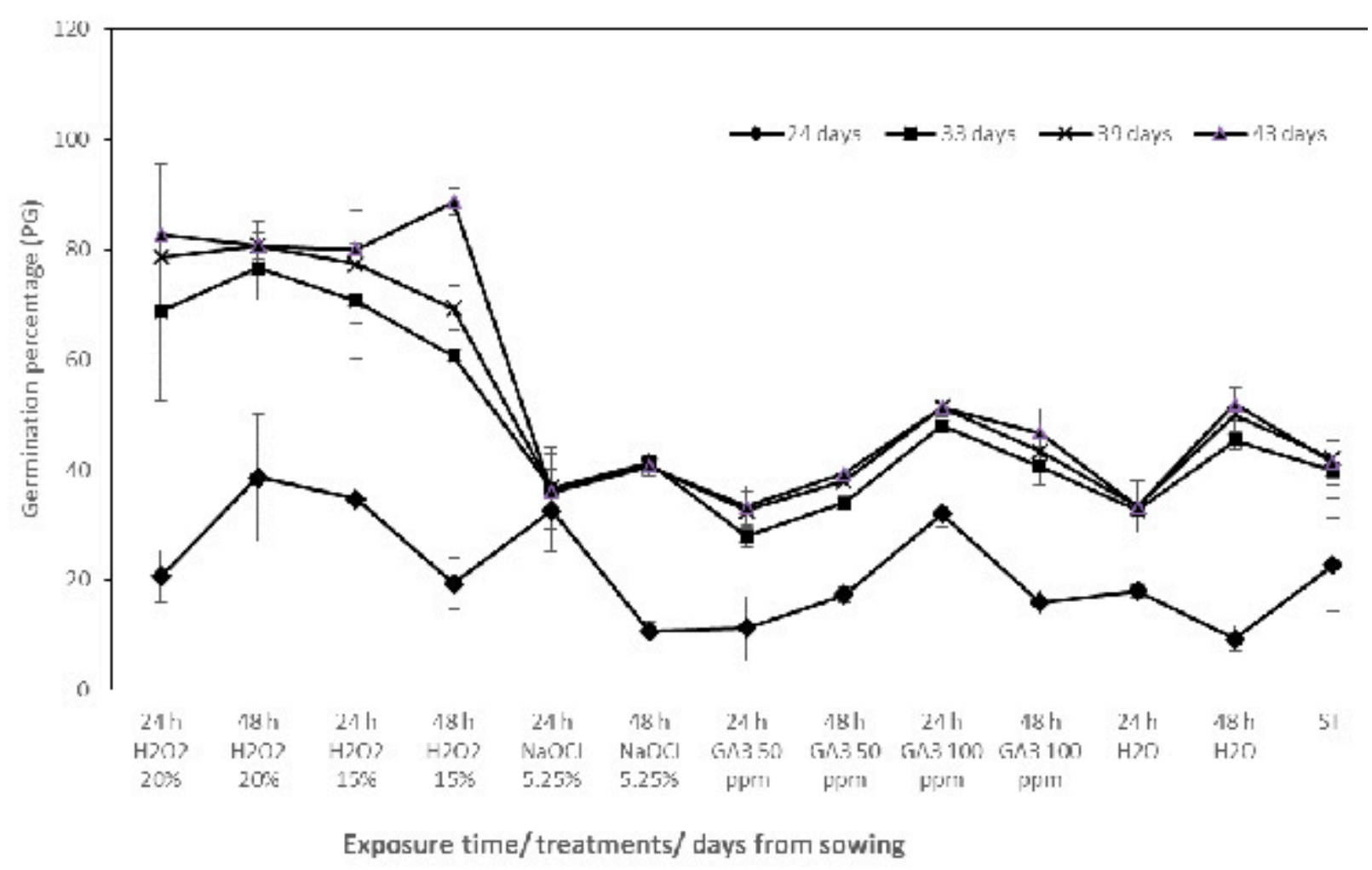

Figure 1. Effect of pretreatments evaluated in the germination percentage (PG) of seeds of P. edulis $\mathrm{f}$ edulis at 24, 33,39 and 43 days from planting.

The use of sodium hypochlorite had not been reported as a treatment inducer in pasiflora seeds, but in species with germination difficulties by the presence of a thick and waterproof testa as in the genus Rubus had already been tested its effect had already been proven inductor and others that had the presence of chemical compounds possibly inhibitory of germination as in Carica papaya. In seeds of Rubus glaucus immersed in $\mathrm{NaOCl}$ $5.25 \%$ for 16 hours, improved germination by $88.33 \%$ (DÍAZ et al., 2013) and 58.28\% (VASQUEZ et al., 2019). It seems that sodium hypochlorite works by disintegrating the testa and accelerating the germination process to 10 days while the treatment witnesses germination starts at 90 days. In seeds of Carica papaya, the presence of phenolic compounds in the exotesta negatively affects germination, immersion for 24 hours in $\mathrm{NaOCl}$ to $2 \%$ of active chlorine, increased and accelerated the emergence of seedlings registering values between 60 to $80 \%$ PG (JESUS et al., 2016).

Additionally, the use of $\mathrm{NaOCl}$ in seed disinfection processes is widely known. In contrast, in this research treatments with 24 and 48 hour sodium hypochlorite had lower PG, 36 and $40 \%$ values to pretreatments with hydrogen peroxide and similar to those observed with $\mathrm{GA}_{3}$ at $50 \mathrm{ppm}$, but lower than those recorded with water imbibition for 48 hours which recorded up to $52 \%$ PG. In the case of $\mathrm{GA}_{3}$, a growth regulator used in most published trials as a germination inducer, the PG achieved, in concentrations of $50 \mathrm{ppm}$, in 24 and 48 hours of exposure, was 33.3 and $39.3 \%$, respectively. At higher concentrations, $100 \mathrm{ppm}, \mathrm{PG}$ increased, registering between 51.3 and $46.7 \%$, to 24 to 48 hours of exposure.

In this research with respect to giberelins, the highest $P G$ values were presented in pretreatment with 100 ppm of $\mathrm{GA}_{3}$, with $\mathrm{PG}$ recorded of 51 and $46 \%$, in exposure times of 24 and 48 hours. At a lower concentration, $50 \mathrm{ppm}$, in 24 and 48 hours of exposure, PG was 33.3 and 39.3\%, respectively. Similar results were obtained by Marostega et al. (2017) when evaluating pre-germinative treatments for six species of ornamental pasifloras, including immersion in gibberellic acid $\left(\mathrm{GA}_{3}\right)$, obtaining between 54 and $86 \%$ germination for the evaluated species. In contrast, in other research, the imbibition in gibberellic for 24 hours at $1 \mathrm{mg}$ $\cdot \mathrm{ml}^{-1}$, recorded high germination rates, $94 \%$, much higher than that recorded for our tests.

The gibberellins control different states of plant development, including seed germination, seedling growth, stem elongation, among these is the gibberellic acid that stimulates seed germination, has a vital role in plant growth and development, flower development and fruit expansion, pollination, among others (VISHAL; KUMAR, 2018). Several studies have shown that gibberellins shades play a vital role in a large number of biological and physiological activities, when applied exogenously. Treatments in the presence of different 
$\mathrm{GA}_{3}$ concentrations for dormancy rupture and/or germination induction with varying effectiveness in the percentages obtained have been evaluated in numerous reports. Effectiveness depends on the genus, species, concentration and time of immersion or exposure of the seed (CAVUSOGLU; SULUSOGLU, 2015).

The seeds that were extracted from the fruit (No treatment. ST), washed and sown directly, under the same substrate and irrigation conditions as the seeds used in the other treatments, had relatively high values and comparable to some of the chemical treatments, $41 \%$ PG. Water imbibition, from the physiological point of view is the first phase of germination and rehydration is from the physio-biochemical point of view (HARTMANN et al., 2002; DORIA, 2010). The ingress of water into the seed is due exclusively to a difference in water potential between the seed and the surrounding medium (MATILLA, 2008). In most trials water imbibition is used as a control treatment, in this investigation the imbibition in distilled water at the same exposure times evaluated in the other treatments, show a slight increase in the PG with respect to control (ST), quantifying a PG of $52 \%$ with exposure time of 48 hours. However, this value is much lower than the $88 \%$ achieved with pretreatment in hydrogen peroxide. The results for the shoot length of gulupa, seedling are in agreement with those observed for germination percentage, treatments with peroxide of hydrogen offered, in general shoot length between 2,7 to $2,9 \mathrm{~cm}$. The lowest values were recorded in pretreatments with cold stratification and sodium hypochlorite for 48 hours.

Statistical analysis of the TGM germination index showed that there were no significant differences in this parameter between the different treatments. The treatment in which germination occurred in a shorter time, 24.9 days, compared to the others was that of $\mathrm{NaOCl}$ with exposure time of 24 hours and the highest TMG was presented in $\mathrm{H}_{2} \mathrm{O}_{2}$ at $15 \%$ for 48 hours, 32 days. However, in these treatments for the $\mathrm{NaOCl}$ presented one of the lowest PG and for $\mathrm{H}_{2} \mathrm{O}_{2}$ at $15 \%$ the PG was the highest. During the seed stratification process of some species, there is a decrease in the physiologically active form of abscisic acid - ABA (ABA-free), with the consequent increase in germination capacity (MATILLA, 2008). The results quantified in stratification at $4{ }^{\circ} \mathrm{C}$ for 7 days with a PG of $62 \%$, are higher than those obtained with some of the chemical treatments in this research, however the 15-day trial under the same temperature conditions decreased the value PG to $46 \%$. In contrast, Velasquez et al (2012) found that seeds evaluated in cold pretreatment at $4{ }^{\circ} \mathrm{C}$ for 15 days and subsequent sowing in the greenhouse at $25{ }^{\circ} \mathrm{C}$, recorded a PG of $75 \%$.

\section{Conclusions}

The results of this research indicate that gulupe seeds treated in immersion with hydrogen peroxide, at the concentrations and exposure times assessed, quantified the best germination rates, compared to other treatments. However, the evaluation of lower concentrations and variable exposure times is necessary to optimize the production protocol of gulupa plants sexually by pretreatment with hydrogen peroxide.

\section{References}

BARBA, E.G.; HERNÁNDEZ, J.A.; DIAZ-VIVANCOS, P. Role of $\mathrm{H}_{2} \mathrm{O}_{2}$ in pea seed germination. Plant Signal and Behavior, Georgestown, v.7, n.2, p.193-195, 2012.

BAILLY, C. The signalling role of ROS in the regulation of seed germination and dormancy. Biochemical Journal, London, v.476, n.20, p. 3019-3032, 2019.

CARDENAS, J. Morfología y tratamientos pregerminativos de semillas de granadilla (Passiflora ligularis Juss.). 2011. 110p. Tesis (Maestría en Ciencias Agrarias) - Universidad Nacional de Colombia, Bogotá, 2011.

CARVAJAL, V.; ARISTIZABAL, M.; VALLEJO, A. Caracterización del crecimiento del fruto de la gulupa (Passiflora edulis f. edulis Sims). Agronomía, Manizales, v.20, n.1, p.77-88, 2012.

CAVUSOGLU, A.; SUlUSOGLU, M. The Effects of exogenous gibberellin on seed germination of the fruit species. Türk Bilimsel Derlemeler Dergisi, Ankara, v.8, n.1, p.6-9, 2015.

CERQUEIRA, S.C.B.M.; FALEIRO, F.G.; de JESUS, O.N.; DOS SANTOS, E.S.L.; de SOUZA, A.P. Passion fruit (Passiflora spp.) breeding. In: AL-KHAYRI J.; JAIN S.; JOHNSON D. (Ed.). Advances in plant breeding strategies: fruits. London: Springer, 2018. $988 \mathrm{p}$.

DELANOY, M.; VAN DAMME, P.; SCHELDEMAN, X.; BELTRAN, J. Germination of Passiflora mollissima (Kunth) LH Bailey, Passiflora tricuspis Mast. and Passiflora nov sp. seeds. Scientia Horticulturae, Amsterdam, v.110, n.2, p.198-203, 2006.

DÍAZ, D.C.A.; LOBO, A.M.; CARTAGENA, V.J.R.; MEDINA, C.C.I. Dormancy and germination of Castilla blackberry seeds (Rubus glaucus Benth). Revista Facultad Nacional de Agronomía Medellín, Medellín, v.66, n.1, p.6855-6864, 2013. 
DORIA, J. Generalidades sobre las semillas: su producción, conservación y almacenamiento. Cultivos Tropicales, La Habana, v.31, n.1, p. 74-85, 2010.

ELLIS, R. H.; HONG, T. D.; ROBERTS, E. H. Handbook of seed technology for genebanks. Principles and methodology. Roma: International Board for Plant Genetic Resources. Handbooks for Genebanks, 1985. $456 \mathrm{p}$.

FALEIRO, F.G.; JUNQUEIRA, N.T.V.; JUNGHANS, T.G.; JESUS, O.N.; MIRANDA, D.; OTONI, W.C. Advances in passion fruit (Passiflora spp.) propagation. Revista Brasileira de Fruticultura, Jaboticabal, v.41, n.2, e-155, 2019.

FERREIRA, D.F. Sisvar: A guide for its bootstrap procedures in multiple comparisons. Ciência e Agrotecnologia, Lavras, v.38, n.2, p. 109-112, 2014.

FICHMAN, Y.; MILLER, G.; MITTLER, R. Whole-plant live imaging of reactive oxygen species. Molecular Plant, Shangai, v.12, n.9, p.1203-1210, 2019.

FRANCO, G.; CARTAGENA, J.R.; CORREA, G. Análisis de crecimiento del fruto de gulupa (Passiflora edulis sims), en las condiciones ecológicas del bosque húmedo montano bajo de colombia. Revista UDCA Actualidad \& Divulgación Científica, Bogotá, v.17, n.2, p.391-400, 2014.

GRZYBOWSKI, C.R.S.; SILVA, R.C.; BELNIAKI, A.C.; PANOBIANCO, M. Investigation of dormancy and storage potential of seeds of yellow passion fruit. Journal Seed Science, Londrina, v.41, n.3, p.367-374, 2019.

GUTIÉRREZ, M.I.; MIRANDA, D.; CÁRDENAS H.J.F. Efecto de tratamientos pregerminativos sobre la germinación de semillas de gulupa (Passiflora edulis Sims.), granadilla (Passiflora ligularis Juss.) y cholupa (Passiflora maliformis L.). Revista Colombiana de Ciencias Horticolas, Tunja, v.5, n.2, p.209-219, 2011.

HARTMANN, H.T.; KESTER, D.E.; DAVIES Jr, F.T.; GENEVE, R.L. Techniques of propagation by seed. Plant propagation, principles and practices $7^{\text {th }} \mathrm{ed}$. New Jersey: Prentice Hall, 2002. p.249-274.

HEJAZI, Z.; SADAT, M.; RAGHIB, M.; ZERAK, A.; FITRAT, K. Effect of Different Concentrations of GA, $\mathrm{H}_{2} \mathrm{O}_{2}$ and Bleach Solutions on Seed Germination of Guava (Psidium guajava L). International Journal of Chemical Studies, New Delhi, v.6, n.5, p.2679-2681, 2018.
ICONTEC - Instituto Colombiano de Normas Técnicas y Certificación. Frutas frescas: granadilla. Bogotá: ICONTEC, 1997. 20p. (NTC, 4101)

ISTA - International Seed Testing Association. International rules for seed testing. Switzerland: International Seed Testing Association, 2013. 284p.

JESUS, V.A.M.D; ARAÚJO, E.F.; NEVES, A.A.; SANTOS, F.L.; DIAS, L.A.D.S.; SILVA, R.F.D. Ratio of seeds and sodium hypochlorite solution on the germination process of papaya seeds. Journal of Seed Science, Londrina, v.38, n.1, p.57-61, 2016.

LARIGUET, P.; RANOCHA, P.; DE MEYER, M.; BARBIER, O.; PENEL, C.; DUNAND, C. Identification of a hydrogen peroxide signalling pathway in the control of light-dependent germination in Arabidopsis. Planta, Berlin, v.238, n.2, p.381-395, 2013.

MABUNDZA, R.M.; WAHOME, P.K.; MASARIRAMBI, M.T. Effects of different pre-germination treatment methods on the germination of passion (Passiflora edulis) seeds. Journal of Agriculture and Social Sciences, Faisalabad, v.6, n.1, p.57-60, 2010.

MAROSTEGA, T.N.; LUZ, P.B.; TAVARES, A.R.; NEVES, L.G.; SOBRINHO, S.P. Methods of breaking seed dormancy for ornamental passion fruit species. Ornamental Horticulture, Campinas, v.23, n.1, p.72-78, 2017.

MATILLA, A.J. Desarrollo y germinación de las semillas. In: J. AZCÓN-BIETO AND M. TALÓN. (Ed.). Fundamentos de fisiología vegetal. Barcelona: McGrawHill-InterAmerican, 2008. p.537-558.

NANDI, M.; PERVEZ, Z.; ALAM, M.S.; ISLAM, M.S.; MAHMUD, M.R. Effect of hydrogen peroxide treatment on health and quality of chilli seed. International Journal of Plant Pathology, New York, v.8, n. 1, 8-13, 2017.

NONOGAKI, H. Seed biology updates - Highlights and new discoveries in seed dormancy and germination research. Frontiers in Plant Science, Lausanne, v.8, n.524, p.1-16, 2017.

ORJUELA, B.N.M.; CAMPOS, A.S.; SÁNCHEZ, N.; MELGAREJO, L.M.; HERNÁNDEZ, M.S. Propuesta de norma técnica colombiana, frutas frescas, gulupa, especificaciones. In: MELGAREJO, L.M.; HERNÁNDEZ, M.S. (Ed.). Poscosecha de la gulupa (Passiflora edulis Sims). Bogotá: Universidad Nacional de Colombia, 2011. 14p. 
PÁDUA, J.G. Germination of Passiflora setacea seeds and storage induced dormancy. Revista Brasileira de Sementes, Brasilia, DF, v.33, n.1, p.80-85, 2011.

RAMÍREZ, J.G.; MUÑOZ, M.; OSORNO, L.; OSORIO, N.W.; MORALES, J.G. Germination and growth of purple passion fruit seedlings under pre-germination treatments and mycorrhizal inoculation. Pesquisa Agropecuaria Tropical, Brasilia, DF, v.45, n.3, p.257-265, 2015.

RANAL, M.A.; SANTANA, D.G.D. How and why to measure the germination process? Brazilian Journal of Botany, São Paulo, v.29, n.1, p.1-11, 2006.

SASAKI, K.; KISHITANI, S.; ABE, F.; SATO, T. Promotion of seedling growth of seeds of rice (Oryza sativa L. cv. Hitomebore) by treatment with $\mathrm{H}_{2} \mathrm{O}_{2}$ before sowing. Plant Production Science, Nagoya, v.8, v.5, p.509-514, 2005.

Silva, G.C.; BOtTOLI, C.B.G. Analyses of Passiflora compounds by chromatographic and electrophoretic techniques. Critical Reviews in Analytical Chemistry, London, v.45, n.1, p.76-95, 2014.

SILVA, R. M.; AGUIAR, A.V.M.; GARCIA, K.G.V.; FALEIRO, F.G.; MENDONÇA, V.; CARDOSO, E. Germination and interspecific grafting of passion fruit. Comunicata Scientiae, Bom Jesus, v.9, n.3, p.531534, 2018.

SZOPIŃSKA, D. Effects of hydrogen peroxide treatment on the germination, vigour and health of Zinnia elegans seeds. Folia Horticulturae, Krakow, v.26, n.1, p.19-29, 2014.
THOMPSON, P.A. Characterization of the germination, response to temperature of species and ecotypes. Nature, London. v.225, n.1, p.827-831, 1970.

VÁSQUEZ, W.; PUPIALES, P.; VITERI, P.; SOTOMAYOR, A.; FEICAN, C.; CAMPAÑA, D.; VIERA, W. Escarificación química y aplicación de ácido giberélico para la germinación de semillas de cultivares de mora (Rubus glaucus benth). Interciencia, Santiago, v.44, n.3, p.161-166, 2019.

VELÁSQUEZ J.D.; MELGAREJO L.M.; STANISLAV M. Tratamientos pregerminativos en semillas de Gulupa Passiflora edulis Sims. In: MELGAREJO, L.M. (Ed.). Ecofisiología del cultivo de la gulupa (Passiflora edulis Sims). Bogotá: Universidad Nacional de Colombia, 2012. p.84-89.

VISHAL, B.; KUMAR, P. P. Regulation of seed germination and abiotic stresses by gibberellins and abscisic acid. Frontiers in Plant Science, Lausanne, v.9, n.838, p.1-15, 2018.

WILLIS, C.G.; BASKIN, C.C.; BASKIN, J.M.; AULD, J.R.; VENABLE, D.L.; CAVENDER-BARES, J.; DONOHUE, K.; RUBIO DE CASAS, R.; WILCZEK, A. The evolution of seed dormancy: Environmental cues, evolutionary hubs, and diversification of the seed plants. New Phytologist, Lancaster, v.203, n.1, p.300309, 2014.

WOJTYLA, Ł.; LECHOWSKA, K.; KUBALA, S.; GARNCZARSKA, M. Different modes of hydrogen peroxide action during seed germination. Frontiers in Plant Science, Lausanne, v.7, n.66, p.1-16, 2016. 